UDC $621.372 .55: 621.382 .333 .32$ $621.3 .018 .14: 621.3 .018 .7$

\title{
サイリスタを用いたスイッチングフィルタ によるひずみ波の力率改善
}

$\begin{array}{lllll}\text { 東京工業大学 } & \text { 深 } & \text { 尾 } & \text { 正 } \\ \text { 東京工業大学 } & \text { 飯 } & \text { 田 } & \text { 等 } \\ \text { 東宗工業大学 } & \text { 宮 } & \text { 入 } & \text { 庄 } & \text { 太 }\end{array}$

\section{1.まえがき}

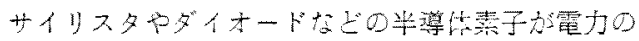

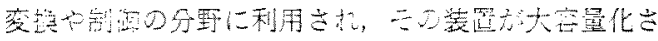

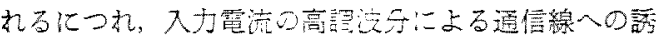

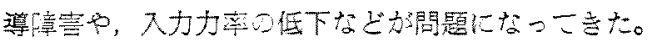

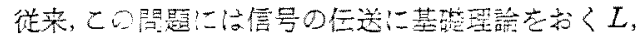

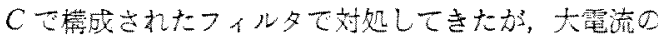
うえに比颙的低周波のため，L，Cのサイズ加大音く

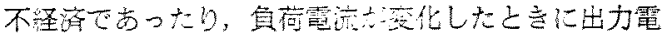

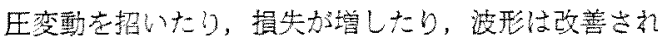

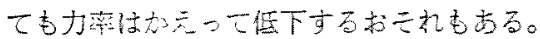

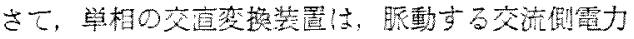

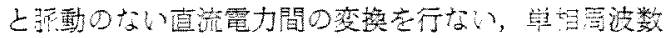

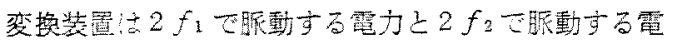

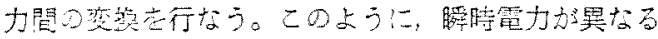

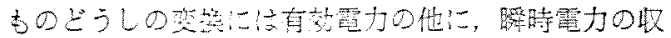

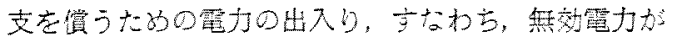
记要になる。

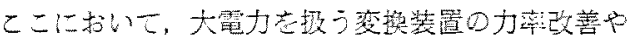

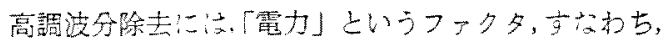

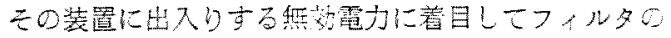

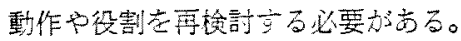

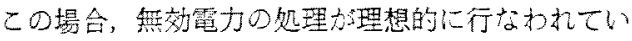

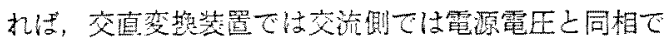

Potrer Factor Improvement of a Non-Sinusoidal A.C. Circuit by Thyristor Switching Fitter. By T. FUKAO, Member, H. IIDA, Associate \& S. MTYAIRI, Member (Tokyo Institute of Technologil

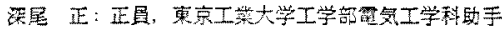

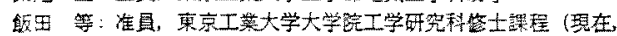
港松テレビ林式会杜)

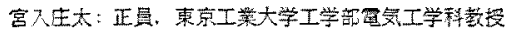

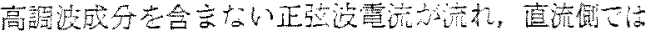
眽動のはい直流が得られる。そしてこの作质を果市

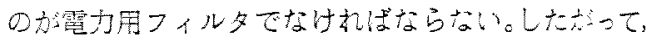

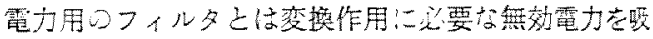

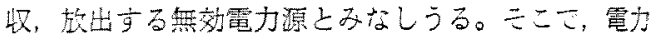

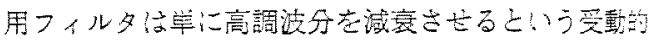
なフィルタとは異なり，必要に応して電力在出し入れ させる能動的枝ものでなてはならない。

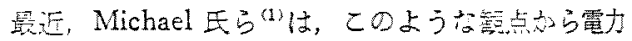
用フィル夕を諭じ，ひ文み波の皮相電力 $S$ を有效䉓

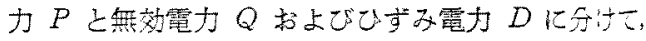
$Q$ 上 $D$ 上を補償する方法について述へている。

同氏bの方洼は，第1困（a）の非線形真荷への日

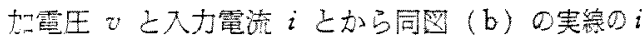

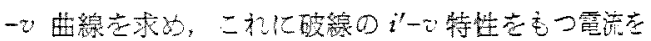

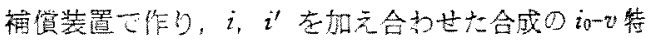

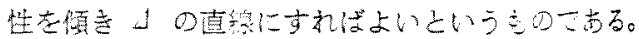

上ころがここで提案されこいる補償装羁はスイッ チ素子と抵抗，あるいはスイッチ秦子とリアクトル，

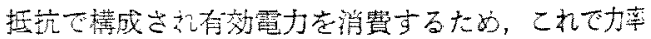

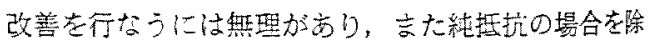

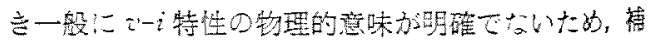
償㳖置で作るべき電力波形（およざ最）上無效電力， ひずみ電力とを結びつけて考えることが固藉である。

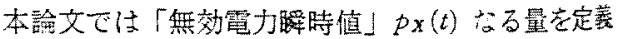
l，このpx(t)を生ずる無效電力源 $X$ を第 2 四のよ

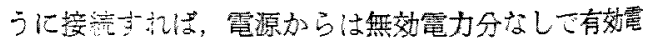
力のみが送られ，理想的䉓力変换方てきるという点 に着目した新しい電力用フィルタの榜想を提案する。

ここで， $p_{X}(t)$ は一般に複雑な波形で，これ忠案

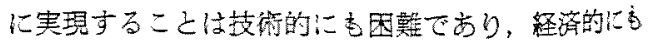




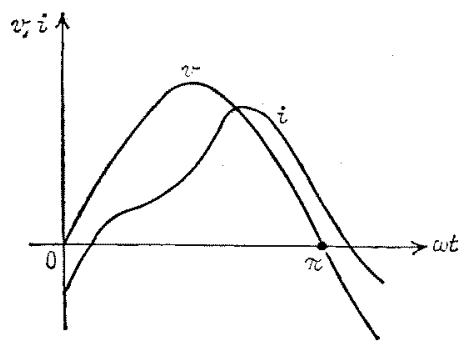

（a）会荷口電流雪王波形

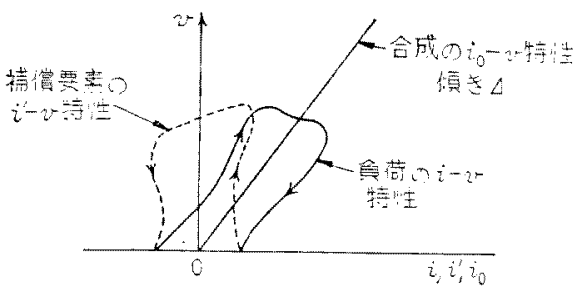

(b) $i-v$ 平面表示

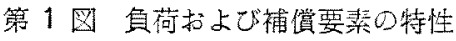

Fig. 1. Characteristics of load and compensator.

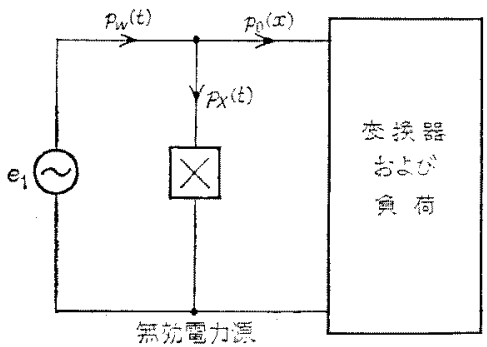

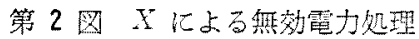

Fig. 2. Compensation of reactive power by $\mathrm{I}$.

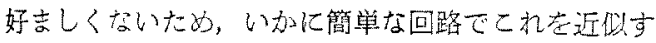

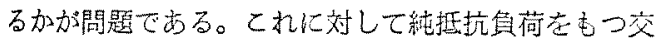
流位相制御回路の然效電力処理を目的にした第 6 四の 回路 (り下，これをスィッチングフィルタと称する) 学考案し，その陲作原理および設計法を明らかにした。

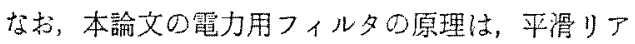

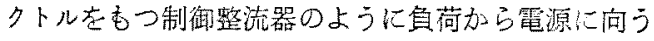

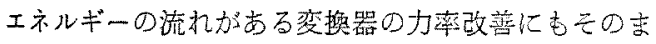
ま適用できる。

\section{2. ひずみ波電力と力率(2)}

いま，正弦波電源 e1からひずみ電流 $i$ が流れてい るとき，瞬時電力 $p_{0}(t)$ は次式で表わされる。

$$
\begin{aligned}
p_{0}(t) & =e_{1} i=e_{1}\left(i_{1}+i_{2}+\cdots+i_{r}+\cdots+i_{n}\right) \\
& =\underbrace{E_{1} I_{1} \cos \phi_{1}(1-\cos 2 \omega t)}_{\text {有她分 }}
\end{aligned}
$$

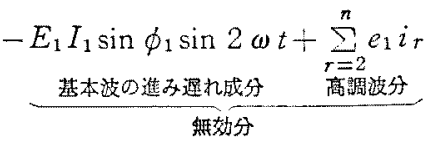

たたし， $e_{1}=\sqrt{2} E_{1} \sin \omega t, \quad i_{1}=\sqrt{2} I_{1} \sin \left(\omega t-\phi_{1}\right)$

(1) 式の右辽第 1 項の一䧓期の平均俌は $E_{1} I_{1} \cos \phi_{1}$ で有效電力, $\cos \phi_{1}$ 在基本波力率と称している。第 2 項は基本波電流の遅れ，または進み成分による变動電 力，第 3 項《高調波成分の変動電力で，いずれ屯一周

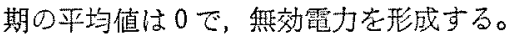

(i) i が正弦波交流のときはひずみ電力は0て

$$
\sum_{r=2}^{n} e_{1} i_{r}=0
$$

この場合の打率 $\cos \varphi$ は

$\cos \varphi=\cos \phi_{1}=$ 有效電力/皮相霆力

(ii) 正弦波交流でかつ $\cos \phi_{1}=1$ のとき

$$
p_{0}(t)=E_{1} I_{1}(1-\cos 2 \omega t)
$$

これは純抵抗負荷時で，雷力伝送ししては一番㚥ま しい状態であるが，この場合にむ雷力の瞬時值には眽 動吕あることに过目すべきである。

（夏）一般の堤合〔の場合の力率は総合力率ま たは等価力率上いい，(2)式をそのまま摭張して，次 式で定義されている。

総合力率二有効電力/皮相霞力

第3図（a）でサイリス多の点报角 $\alpha$ をたとえば $60^{\circ}$ 一定に保ち，コンデンサCの容最老変えた場合 の力率計の清示は（b）困の曲線（て，曲線 II の基 本波打率の計算值と $2 \%$ 部差内でよく一致する。乙 こで，徉来の力率計は基本波力率を示すように作られ ていることがわかる。また（4）式により総合力率を 計算すると曲線 III が得られ，V，I，W の測定結 果加ら求め大曲線 IV 上测定䛊差䉇围で一致する。

このように，綾合力率は波形がひずんでいる限り 1 冈下て，これをコンデンサまれはりアクトルで補筫し て1にするこしはできない。すなわち，(1)式で右包 第2 項はコンデンサまたはりアクトルでに代き， (b)四のコンデンサ容置 $Q_{0}$ がこれに想当し，曲線 II NV は最大值をとるが，第 3 項のために 1 にはならな い。ここでさらにC を增すと，第2 項の進子無效分 加堌して力率は但下する。

ところで，従来の総合力率では進躇れの意昧が明 確でなく，(i)総合力率を進み逑れいずれの領域にプ ロットしたらよいか，（ii）曲線 耳， IV のようにする と $C$ が $Q_{0}$ より大さくなると基本波力率级進みであ

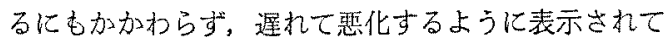

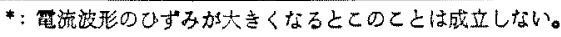




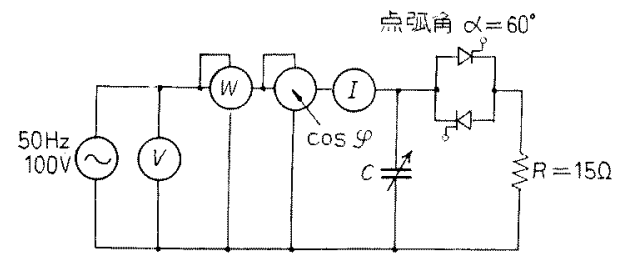

(a)

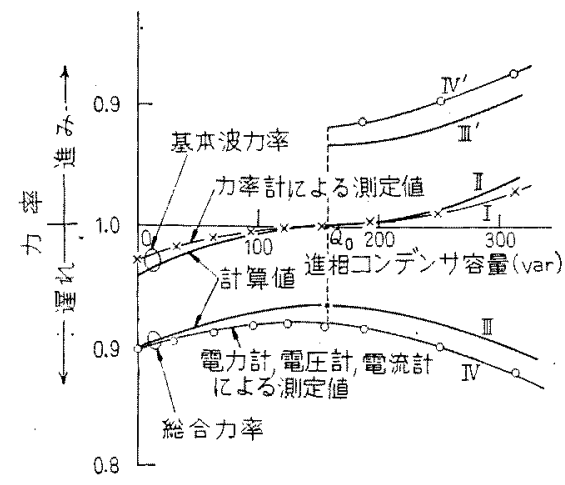

(b)

第3 図ひずみ波力率の测定招よび表示法

Fig. 3. Method of the measurement and the representation of power factor of a non sinusoidal AC circuit.

しまうなどの問題がある。そこで，基本波力率の進み 遲れで総合力率の進み遅れをいうことにし，曲線III， IV を III'， $\mathbb{N}^{\prime}$ のようにする。こうすると総合力率は $\cos \phi_{1}=1$ となる $Q_{0}$ で不連続になり，ここでは基本 波力率は 1 で高調波成分によって総合力率䚮低下して いることが加る。

一方，これ以外の点では総合力率の低下は基本波力 率の進み遅れ成分に上る手のか，高調波分の寄与が大 きいかの判断はできないという問題は残されている が，（ii）の矛盾は解決され基本波力率の進み退れは明 確になる。

\section{3.ひずみ波の無効電力瞬時值 $\boldsymbol{p}_{\boldsymbol{X}}(\boldsymbol{t})$ の定義}

すでに述へたとおり，交直や周波数变換などの変換 作用には無効電力が重要な役割をはたすにもかかわら ず，定義が明整でなく，特にひずみ波の然效電力瞬時 值に対する報告は籍者らの知る螌围では皆鿏である。

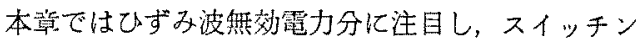
グフィルタの基礎となる瞬時値 $p_{X}(t)$ を定義する。

〈3.1〉 正弦波交流電力の無効分と力率改善 式で $i$ が正弦波の場合，右辺第 1 項，2 項を

$$
\left.\begin{array}{l}
p_{W}(t) \equiv E_{1} I_{1} \cos \phi_{1}(1-\cos 2 \omega t) \\
p_{X}(t) \equiv E_{1} I_{1} \sin \phi_{1} \sin 2 \omega t
\end{array}\right\}
$$

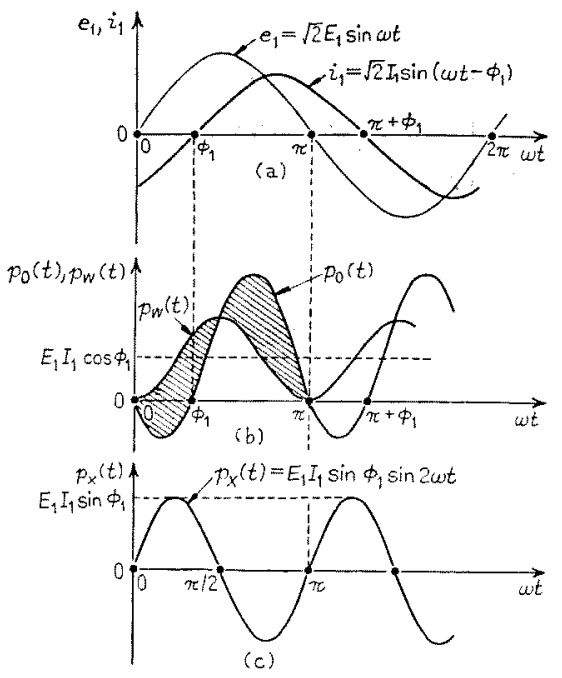

第 4 図 $e_{1}, p_{0}(t), p_{W}(t)$ および $p_{x}(t)$ の関係 Fig. 4. Relation between $e_{1}, p_{0}(t), p_{\omega}(t)$ and $p_{X}(t)$.

とおけば（1）式の次のようになる。

$$
p_{0}(t)=p_{w}(t)-p_{X}(t)
$$

第 4 図（b）の斜線部が $p_{X}(t)$ で，(c) 図の角周 波数 $2 \omega$ の正弦波になり，最大值 $E_{1} I_{1} \sin \phi_{1}$ を無効 電力と定義しているととは，周知のと拈りである。

ここで, この回路の力率改善とは, 負荷に並列にコ ンデンサまたはリアクトルを入れて $p_{X}(t)=0$ とし， 電源加ら送られる瞬時電力を (3) 式の純抵抗目荷時 と同じ形にして, 有効電力 $W=E_{1} I_{1} \cos \phi_{1}$ のみ老理 想的な形で送るようにすることである。

このことから次の結論が得られる。

(1) $e_{1}=\sqrt{2} E_{1} \sin \omega t$ の電源加ら電力 $W$ を送 る理想的な方式はその瞬時電力が次式で表わされる場 合である。

$$
p_{W}(t)=W(1-\cos 2 \omega t) .
$$

（2）古万負荷化送られる有效電力か（7）式の $W$, 瞬時電力が $p_{0}(t)$ であれば，負荷のもつ䊈効分は

$$
p_{X}(t)=p_{W}(t)-p_{0}(t)
$$

で表扣さ机る。

\section{〈3.2〉ひずみ波電力への拡張 （1）式で}

$$
E_{1} I_{1} \sin \phi_{1} \sin 2 \omega t-\sum_{r=2}^{n} e_{1} i_{r} \equiv p_{x}(t)
$$

とおけば，（8)式はこのままひずみ波電力沉搪張でき る。たとえば，第 5 図（a）の純抵抗負荷 $R_{0}$ をむ 回路で点弧角を $\alpha$ とすると，負荷に送られる踩時笔 力 $p_{0}(t)$, 有效電力 $W$ はそれぞれ, 


$$
\begin{aligned}
& p_{0}(t)\left\{\begin{array}{lr}
=0 & (0 \leq \omega t<\alpha) \\
=\left(E_{1}^{2} / R_{0}\right)(1-\cos 2 \omega t) & (\alpha \leq \omega t<\pi) \\
\ldots \ldots \ldots \ldots \ldots \ldots \ldots \ldots(9) \ldots \ldots \ldots \ldots \ldots \ldots
\end{array}\right) \\
& W=\frac{\omega}{\pi} \int_{0}^{\pi / \omega} p_{0}(t) d t=\frac{E_{1}^{2}}{\pi R_{0}}\left(\pi-\alpha+\frac{\sin 2 \alpha}{2}\right)
\end{aligned}
$$

この $W$ を無効電力なしに電源加负荷に送るため の電打伝送波形は（7）式で表わされればならない。

$$
p_{w}(t)=\frac{E_{\mathrm{l}}^{2}}{\pi R_{0}}\left(\pi-\alpha+\frac{\sin 2 \alpha}{2}\right)(1-\cos 2 \omega t)
$$

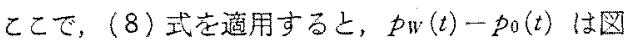
の斜線部の波形になり，面積 $S_{1}$ 二面積 $S_{2}$ であるか ら一周期の平均値は0で，こ机をひずる波の然効電力 瞬時值 $p_{X}(t)$ と定義する。すなおち，

$$
p_{x}(t) \begin{cases}=W(1-\cos 2 \omega t) & (0 \leq \omega t<\alpha) \\ =\left(W-E_{1}^{2} / R_{0}\right)(1-\cos 2 \omega t) & (\alpha \leq \omega t<\pi)\end{cases}
$$

〈3.3〉 電力用非線形フィル夕 この $p_{x}(t)$ を生 ずる無効電力源 $X$ が実現できると，乙れ第 5 図 （a）の破線の上うに接秸し，負荷拉上び位相制御回路 とXの間で变换化必要な無効電力をすべてやりとり させれば，電源からは力率 1 で理想的な電力㐾送がで き，無効電力の補償要素，すなわち，新しい形の電力 用フィルタの設計目標か明らかになる。

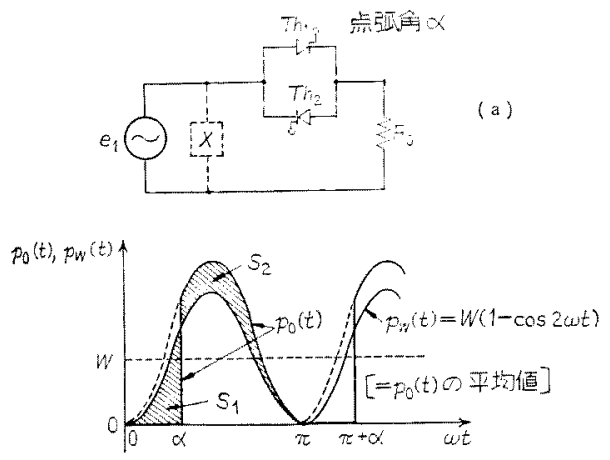

(b)

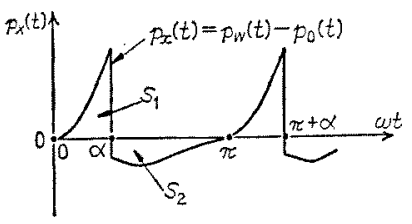

(c)

第 5 図ひずみ波無効電力瞬時值 $p_{x}(t)$ の定義

Fig. 5. Definition of the instantaneous value of distortive power $p x(t)$.

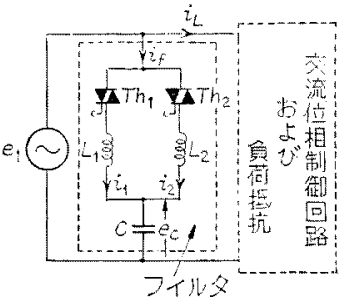

(a) Type1つィル夕 $\left(0<\alpha_{f}<90^{\circ}\right)$

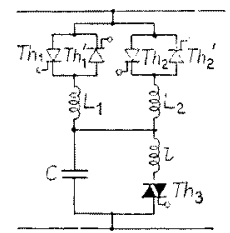

(b) Type 27 イル $\left(90^{\circ}<\alpha,<180^{\circ}\right)$
笎 6 図 スイッテングフィルタ回路

Fig. 6. Switching filter circuits.

\section{4. スイッチングフィルタ回路}

第6 図が本論文で述べるスイッチングフィルタ回路 で, (a), (b) 二つの Type がある。

\section{〈4-1〉 動作原理}

(a) Type1フィル夕 (a) 图で $T h_{1}, T h_{2}$ はトライアックでも逆並列の SCR でもよい。定常状 態では，第 7 図 $\omega t \leq 0 て ゙ T h_{1} ， T h_{2}$ はオフで，各 サイリスタ電流 $i_{1} ， i_{2}$ ，コンデンサ電圧 $e_{c}$ (いず机す 第 6 図の矢印方向を正にとる) は, $i_{1}=i_{2}=0, e_{c}=-E_{c 1}$ である。

モードIこの状態て $T h_{1}$ を点弧すると $(\omega t$ $=0), i_{1}$ は正方向に $e_{1}-T h_{1}-L_{1}-C-e_{1}$ の回路で 流れ， $e_{c}$ の正方向纪充電され， $\omega t=\alpha_{f}$ で最大值 $e_{c}$ $=E_{c 2}$ に達し， $T h_{1}$ はオフする。

モードII $\quad \omega t=\alpha_{f}$ で直ちに $T h_{2}$ を点弧すると $C$ の電荷は $e_{1}-C-L_{2}-T h_{2}-e_{1}$ の回路で放出され $e_{c}$ は $\omega t=\beta$ て極小檤 $e_{c}=E_{c 1}$ をとり， $i_{2}=0$ にな り，Th: は消弧する。

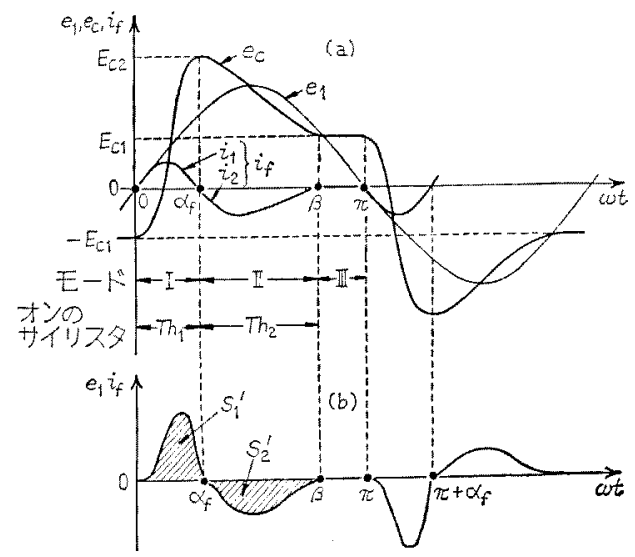

第 7 図 Type 1フィルタ备部の波把

Fig. 7. Current and voltage wave forms in Type 1 filter. 
モード III $\quad \beta<\omega t<\pi$ の期間で， $i_{1}=i_{2}=0, \quad e_{c}$ $=E_{c 1}$ と保たれている。

次の半サイクルでは， $i_{1} ， i_{2}, e_{c}$ の極性が逆転する のみで同じ動作がくり返される。

ここで， $L_{2} C$ の積を大きくすれば $\beta$ む大にできる か， $T h_{2}$ の消坬条件加ら $\beta<\pi$ でくてはならない。 また，この回路では $\alpha_{f}>90^{\circ}$ にはできない。このよ うな必要のあるときには Type 2フィルタを用いる。

(b) Type 2 フィタ 第6図 (b) の棈成で,

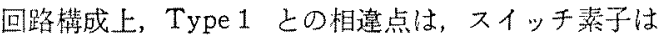
逆並列の SCR でなければならない点**，上l，Th3 を用いて各半周㗅の終わりにe。を反捏する点である。 動作は第 8 図のとおり，モード I，II は Type 1 の それらに対応し， $\omega t=\beta$ で $i_{2}=0, e_{c}=-E_{c 1}$ である。

モードIII工状態で $T h_{3}$ を点弧すると，C$T h_{3}-l-C$ O回路厄 $C$ の電荷は $l C$ の目由振動に上 り放電し，回路の損失を無視すれば $\pi V \overline{l C}$ 後 $e_{c}=E_{c}$ となり振動は停止する。

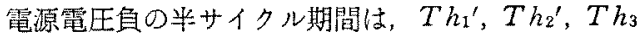
加同様の動作苍行なう。

このようにしてよ゙ちらのフィルタ第7図（b）の ように $0<\omega t<\alpha_{f}$ の間では電源加ら西積 $S_{1}{ }^{\prime}$ に相当 するエネルギーを吸収， $\alpha_{f}<\omega t<\beta$ の間で结 $S_{2}{ }^{\prime}$ を 放出する。ここで $\alpha_{f}$ を $\alpha$ に一致させ $S_{1}^{\prime}$ が第 5 图 の $S_{1}$ に等しくなるように $L ， C$ 起選び，位相制御 回路で生ずる無効箽力を好理しようとするのが，この フィルタの基本原理であるが，との場合，

（1）負荷で生ずる無効分它刻々補儥するのではな

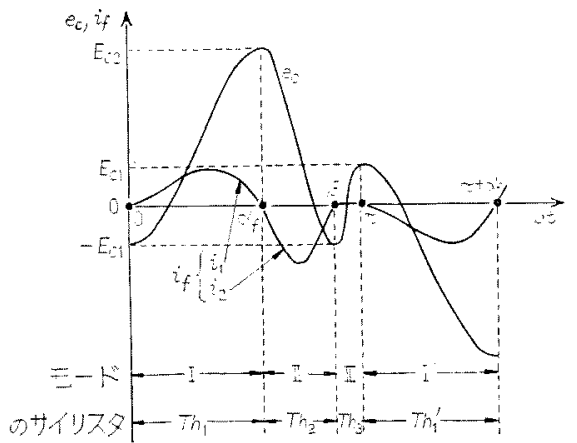

第 8 図 Type 2フィルタの電流電左症形

Fig. 8. Current and voltage forms in Type 2 filter.

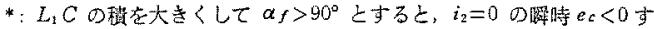

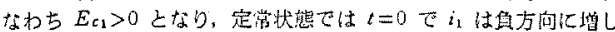

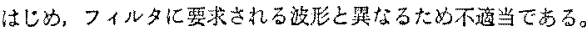

**：トライアックのような双方向性のサイリスタを用いると，珙なった モートで勘作しフフィルとして要求される波形は得ら机い。こ

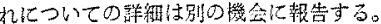

いから，設計点でどの程度力率が改善されるか。また 単純に $S_{1}^{\prime}=S_{1}$ となるように定数を定好て，設計点 で最大の力染が得られるのか。

（2）フィルタそれ自身は高調波の発生回路である から，負荷で生じた高調波索減衰させるどこるか，加 えって発生源になるおるれはないか。

（3） $\alpha$ を広範国に変化させる必要のある場合にフ イルタの效果はよ゙うか。

などを検討する必要がある。

一方ファルタは無效電力を完全には補償できず， 電源の電流波形はある积度ひずむが，このひずみの評 洒基隼として前来の総合力率でじゅうぶんであるのか 別の置を用いたほうがひずみ波電力の性質や特性をよ り明確に表わし，かつフィルタの効果が評価できない 加が問題になるところである。これに対して〈4.5〉で は第 2 章で述べた総合力率で, *〈4.6〉節では電源電流 の高調波含有率でフィルタの効果を判定した。

なお，以下では紙数のつごうならびに，解析や設計 の手斯など Type 1，2 と屯はとんじ同じであるから， Type 1 フィルタについてのみ取り扱う。

$\langle 4 \cdot 2\rangle \boldsymbol{p}_{X}(\boldsymbol{t})$ とコンデンサ蓄積エネルギーの関係 本フィルタの設計の基本は， $S_{1^{\prime}}($ 第 7 図 $)=S_{1}$ (第5図)となるように $L ， C$ を沈めることである。 ここで， $L_{1}$ あるいは $L_{2}$ と $C$ にたくわえられる エネルギー $\varepsilon(t)$ は

$$
\varepsilon(t) \begin{cases}=(1 / 2) L_{1} i_{1}^{2}+(1 / 2) C e_{c}^{2} & \left(0 \leq \omega t<\alpha_{f}\right) \\ =(1 / 2) L_{2} i_{2}^{2}+(1 / 2) C e_{c}^{2} & \left(\alpha_{f} \leq \omega t<\beta\right)\end{cases}
$$

ところが，筹 7 四のとおり， $\omega t=0, \quad \omega t=\alpha$, では $i_{1}=0$ で, フィルタのもつエネルギーはすへて $C$ に たくわえられ，回路の損失，電源の抵沉分を無視すれ ば，Cの蓄棈エネルギーと電源からフィルタに送られ たエネルギーの間には次の関係がある。

$$
\begin{aligned}
& \int_{0}^{\alpha_{f} / \omega} p_{X}(t) d t=\varepsilon\left(\alpha_{f} / \omega\right)-\varepsilon(0)=\frac{1}{2} C\left(E_{c 2}{ }^{2}\right. \\
& \left.-E_{c 1}^{2}\right) \\
& C=\frac{\left(2 \pi-2 \alpha_{f}+\sin 2 \alpha_{f}\right)\left(2 \alpha_{f}-\sin 2 \alpha_{f}\right)}{4 \pi R_{0} \omega\left\{\left(E_{c 2} / E_{m}\right)^{2}-\left(E_{c 1} / E_{m}\right)^{2}\right\}}
\end{aligned}
$$

ただし， $E_{m}=\sqrt{2} E_{1}$ : 電源電目最大值

(15) 式より $0 \leq \omega t<\alpha_{f}$ での $e_{c}$ の初期値 $E_{c 1}$ 上最 終值 $E_{c 2}$ を知れば， $S_{1}{ }^{\prime}=S_{1}$ を満たす $C$ が定まる。

〈4-3〉 $\boldsymbol{E}_{c 1} / \boldsymbol{E}_{m}, \boldsymbol{E}_{c 2} / \boldsymbol{E}_{m}$ 亡回路定数の関係 解 析にあたって次の仮定走おく。

*：以下，特にことわらない限り力滦之は総合力率のことを指す。 
（1）電源は正弦波で内部インピーダンスは0

（2）フィルタ回路の抵抗分は無視*し，サイリス 夕は理想的スイッチ上する。

この级定活いても第 6 图の回路動作は複雑な三角 方程式となり，数值解析によらざるを得ない。**

第9 9 図〜第11 図はこの結果をまよめたものでちる。

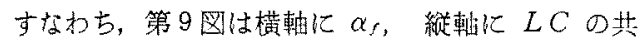
振角周波数之笔源角周波数 $\omega$ ○比， $k_{1} ， k_{2}$

$$
k_{1}=1 / \omega \sqrt{L_{1} C}, \quad k_{2}=1 / \omega \vee \overline{L_{2} C}
$$

をとり，回路が定常動作在行なうたかの $T h_{2} の$ 点弧 角 $\alpha_{f}$ 亡回路定数の関保示している。乙れから， $\alpha_{f}$ を与元机ば $L C$ が洪まり， $L C$ は一定保って $\alpha$ ， のみを連䅧には变えられないととがわかる。

第 10 図は $\alpha_{f}$ 上 $E_{c 1} / E_{m}, E_{c 2} / E_{m}$ の関係老し たもので， $\alpha_{f}$ を大きくすると $E_{c 2}$ は增すが電源電圧 の最大値の 1.5 倍をこえないことがわかる。これをる 之にCやサイリス夕の電正定格が定的られると同時

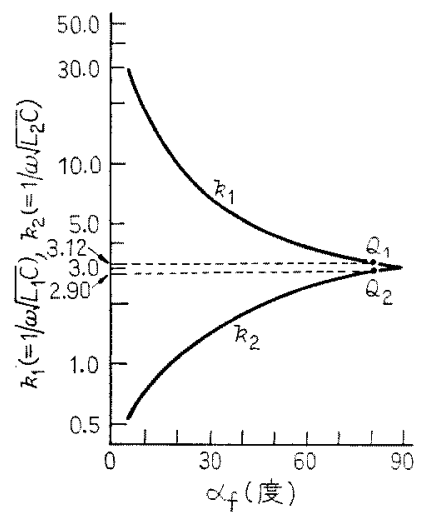

第 9 図 $\alpha_{f}$ と $k_{1}, k_{2}$ の関係 (Type 1フィル夕)

Fig. 9. Relation between $\alpha_{f}$ and $k_{1}, k_{2}$.

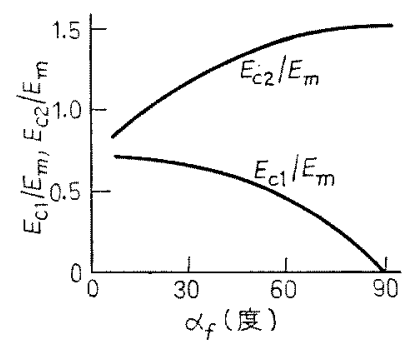

第 10 图 $\alpha_{f}$ z $E_{c 1} / E_{m}, E_{c 2} / E_{m}$ の関係

(Type 1 フィルタ)

Fig. 10. Relation between $\alpha_{f}$ and $E_{c 1} / E_{m}$, $E_{c 2} / E_{m}$

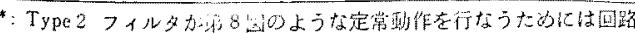

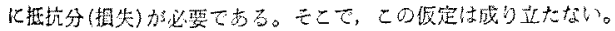

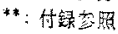

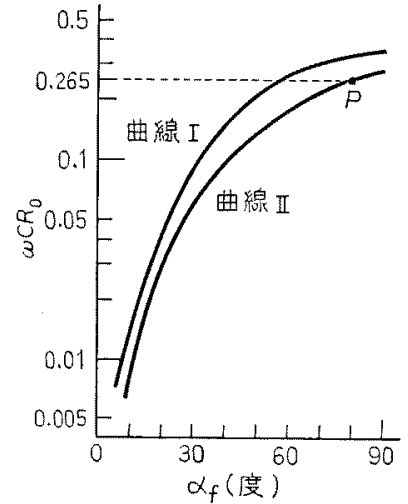

第 11 㘣 $\alpha_{f}$ と ${ } C R_{0}$ D関係 (Type 1 フィルタ)

Fig. 11. Relation between $\alpha_{f}$ and $\omega C R_{0}$.

に（15）式に $E_{c 1} / E_{m}, E_{c 2} / E_{m}$ 在代入し，第 11 図 の曲線工が得られる。

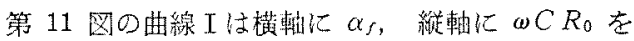
より (15) 式の関係を示し，これより， $R_{0}, \alpha\left(=\alpha_{f}\right)$ が与えられれは， $S_{1}{ }^{\prime}=S_{1}$ 洏たす $C$ の容量が直ちに 求めら机る。

〈4.4〉 $\alpha=\alpha f$ で最大の力率を得るための $C$ の值 本節では第 6 图（a）のフィル夕を付加した位相制 御回路の入力力率在設計点 $\alpha=\alpha_{f}$ で最大にするよう な $C$ の值を求女，(15) 式加ら得られた值と比较し， $S_{1}{ }^{\prime}=S_{1}$ 亡する前節のC の決定法汃，力摔改善已い う锥点加ら適当加否加検討する。

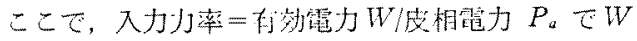
は (10) 式上り，Pa海第6图（a）を参照して

$$
P_{a}=E_{1} \sqrt{\frac{1}{\pi} \int_{0}^{\pi}\left\{i_{L}(\theta)+i_{f}(\theta)\right\}^{2} d \theta}
$$

で与无られ， $i_{L}(\theta) ， i_{f}(\theta)$ は无机天゙れ

$$
\begin{aligned}
& i_{L}(\theta) \begin{cases}=0 & \left(0 \leq \theta<\alpha_{f}\right) \\
=\left(E_{m} / R_{0}\right) \sin \theta & \left(\alpha_{f} \leq \theta \leq \pi\right)\end{cases} \\
& i_{f}(\theta)=i_{1}(\theta)+i_{2}(\theta)=\omega C E_{m} i_{f^{\prime}}(\theta) \\
& x=\omega C R_{0}, \quad A=\int_{\alpha f}^{\hat{\beta}} i f^{\prime 2}(\theta) d \theta \\
& B=\int_{\alpha f}^{\beta} i f^{\prime}(\theta) \sin \theta d \theta, \quad D=\int_{\alpha f}^{\pi} \sin ^{2} \theta d \theta
\end{aligned}
$$

と招忛ば力率は次式で表わされる。

$$
\text { 力就 }=\frac{\pi-\alpha_{f}+\left(\sin 2 \alpha_{f}\right) / 2}{\sqrt{2 \pi} V A x^{2}+2 B x+D}
$$

ここで， $A, B, D$ は $x$ の関数でなく，才率を最大

*: 付録参照 
にする $x$ は次式で与えられる。

$$
x=\omega C R_{0}=-B / A
$$

第 11 図の曲線 II は $\alpha_{f}$ に対する (18) 式の関係 を示している。曲線 I，II を比べると， $R_{0}, \alpha_{f}$ が与 えられると，力率を最大にする $C$ の容量は曲線 II のほうがエより 15〜30\% 程度小さな值である。この ことはまた（18）式から $\alpha_{f} ， C$ が決まれば (15) 式 の $R_{0}$ より小さな值で力率は最大になることを意味す る。こ机は本フィルタでは位相制御回路で生じる無効 電力のうち，高次高調波分を完全には打消せないのに $S_{1}{ }^{\prime}=S_{1}$ となるようにC を決めると，処理できない 高次の高調波無效電力分だけ低次高調波無効分や基本 波の進み成分が增し，設計点の力率は低下することを 示している。そこで, 力率改善の点では曲線 II を用 いて $C$ を決定すべきで，以下ではこれを用いて定数 を決めたフィルタについて解析，実験を行なった結果 を述べる。しかし，どちらの方法で C を決めても設 計点の力率には大差なく，計算によれば曲線 II を用 いたほうが $\alpha_{f}=80^{\circ}$ で約 $2 \%$ 向上するのみであるこ と，また，曲線Ｉは II より容易に計算できることか ら，Cの目安として有用である。

第 9 図〜第 11 図を用いて回路定数が得られる。 たとえば

$$
E_{1}=100 \mathrm{~V}, f=50 \mathrm{~Hz}, R_{0}=10 \Omega, \alpha=80^{\circ}
$$

が与えられているとすると，

$\alpha_{f}: \alpha_{f}=\alpha=80^{\circ}$

$C$ : 第 11 図で $\alpha_{f}=80^{\circ}$ の之き $P$ 点の $\omega C R_{0}$ $=0.265, \omega=2 \pi f, R_{0}=10 \Omega$ より $C=84.5 \mu \mathrm{F}$

$L_{1}$ : 第 9 図で $\alpha_{f}=80^{\circ}$ のとき $Q_{1}$ 点の $k_{1}=3.12$, (16) 式より $L_{1}=1 / k_{1}^{2} \omega^{2} C^{2}=12.9 \mathrm{mH}$

$L_{2}$ : 第 9 図の $Q_{2}$ 点から $k_{2}=2.90$

$L_{2}=1 / k_{2}^{2} \omega^{2} C^{2}=14.5 \mathrm{mH}$

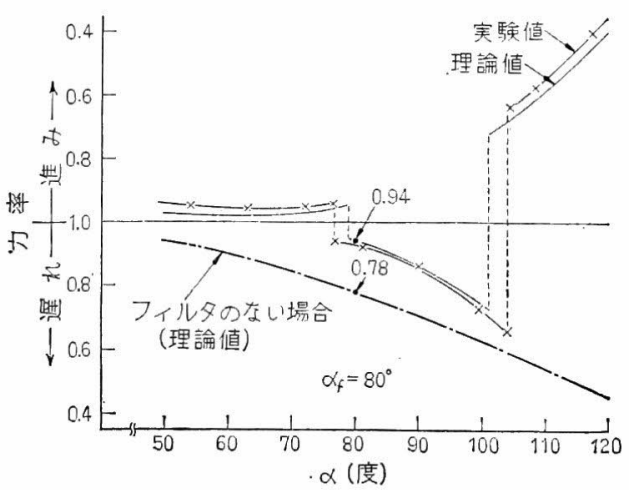

第 12 図 $\alpha$ と力率の関係

Fig. 12. Relation between $\alpha$ and power factor.
スイッチ素子がトライアックの場合, 上記の定数で は平均順電流は $E_{m} / R_{0}$ の $12 \sim 14 \%$ で，Th $2.0 \mathrm{~A} ， T h_{2}$ は $1.68 \mathrm{~A}$ ，最大阻止電圧は $E_{m}$ の $53 \%$ で $75 \mathrm{~V}$ である。

〈4.5〉 力率の改善および $\alpha$ の変化に対する力率の 変化 第 12 図は $\alpha_{f}=80^{\circ}$ の前節の定数のフィル 夕を付加した場合およびフィルタのない場合の位相制 御回路の $\alpha$ を $50^{\circ} \sim 120^{\circ}$ まで変えたときの, 入力力 率の変化の理論值と実験結果を示した。とのグラフよ りフィルタの効果が明らかになる。

（1）計算によれば,ファルタは約 305 VAR の基 本波進み無効分をむち, 一方, 位相制御回路の遅れ無 効分は $\alpha$ を增すにつれ増加し， $\quad \alpha=90^{\circ}$ で最大値約 320 VAR をとり, 以後再び減少する。そこで合成の 基本波力率は $\alpha$ が小では進み， $79^{\circ} \leq \alpha \leq 101^{\circ}$ で遅れ $\alpha \lesssim 101^{\circ}$ で再び進みになる。

(2) 設計点の $\alpha=80^{\circ}$ を中心 $\pm 30^{\circ}$ 程度の $\alpha$ の変化に対し力率の改善ができ, $\alpha=80^{\circ}$ では 0.78 か ら 0.94 になる。

〈4·6〉高調波の除去 第 13 図は位相制御回路の 入力電流 $i_{L}$ と，乙れにフィルタを付加したときの入 力電流 i 0 の波形写真で, 本フィルタでは高次高調波 分を完全には除去できないことがわかる。

第 14 図は前節同様 $\alpha_{f}=80^{\circ}$ のフィルタに対し， $a$

\footnotetext{
上:フィルタなし $(t L) 10 \mathrm{~A} / \mathrm{div}$ 下: フィルタ付加 $\left(i_{0}\right) 10 \mathrm{~A} / \mathrm{div}$ 横朝 $5 \mathrm{~ms} / \mathrm{div}$
}

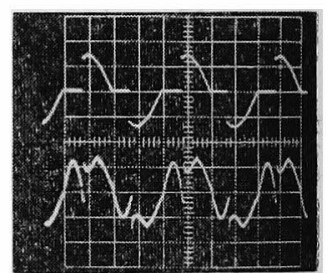

第 13 図 入力電流波形

Fig. 13. Waveforms of input current.

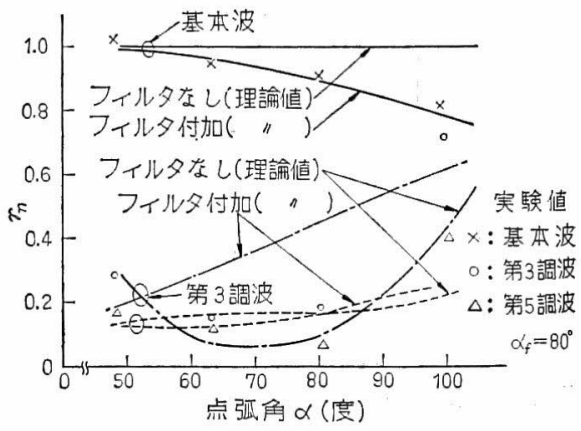

第 14 図 $\alpha$ に対する高調波含有率の変化

Fig. 14. Variation of the harmonic content as a function of firing angle $\alpha$. 
を約 $50^{\circ}$ から $100^{\circ}$ まで変えたときの入力雷流の高調

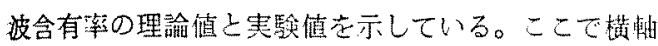
性 $\alpha$, 縦軸 $\gamma_{n}$ は

$\gamma_{n}=\frac{\left(\text { フィル夕を付けた場合の) } n \text { 次調波振幅 } I_{n}\right.}{\text { ᄀィル夕を多付けない場合の甚本波振幅 } I_{01}}$

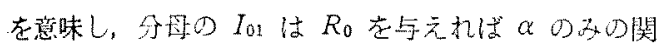
数である。去た，圆中の組被はフィル夕㕱ない場合の $\gamma_{\mathrm{n}}$ で，第3罟波は $\alpha$ につ增加，第 5 調波分はこの れの符国内でほぼ 20\%に一定である。

ここで，フィル夕在付けると理諭的には太線の上う

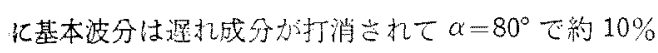
減少，第 3 調波分は $60^{\circ}<\alpha<80^{\circ}$ で基本波の $10 \%$ 以 下になる。一方，第 5 調波はほ上んじ補償されない。 実験の結果，萎本波に関しては理諭値に近い值が得る れるが，第 3 調波分は理論値より大，逆江符 5 調波分 は $\alpha=80^{\circ}$ で理諭僆の半分以下になっている。乙の原 因は理論值はフィルタの $L C D Q$ を無限大乙仮定 したのに対し，実祭は抵抗分のため第7図の及は理 論値上り減少し，第 3 調波の叹収量は減少，第 5 調波 のそれは增したためである。

以上の結果捄よび高次高調波に対する解析から，本 フィルタは（1）基本波の连れ成分上第 3 調波分をじ 中うふん補償できる，(2）第 7，13，15 調波成分は 加えって增すが，增加曾は基本波の $0.3 \%$ 程度で， フ イルタが高調波の発生源になるおそれはないことがわ 加るそこで前節の結果と合わせ，本フィルタが力率 改善之高調波分除去を同時に行なえるととがわかる。

\section{5.むすひ}

本論文ではひずみ波無勃電力瞬時值という新しい概 念を提案し，てれを応用して能動的なフィル夕が模成 できることを示し，一例としてサイリス夕を用いたス イッチングフィルタを考案, 動作原理, 設計法を明ら 加し央験結果を示した。またひずみ波の力率の表 示法に対して，問題点を指摘し一つの提案をした。

その結果, 本論文で得られたフィル夕は力率の改善 と高調波分除去が同時にできるとと，また，従来のL Cフィルタ ${ }^{(3)(4)}$ との儤劣の判定を行なう場合には，負 荷の特性や仕様，使用条件たとえ代高調波の娍衰度， 重量や体皘，洒格など，どれを重視するかにより異な り，これらを教慮せずに一般的な判定を下すことは困 難であるが，本フィル夕は次の 2 点に执いてすぐれて いることが明らかになった。

（1）直列インピーダンスがな゙，負荷が变化して
出力電压が变县したり，負荷に悪影響を与えない。

（2）フィル夕には無效分のみ加出入りし，その工 ホルギーを必要に忍じて制御し，むだな流れが生じな いため琹子の容舅が小さくてすみ, フィルタの小形, 轻量化方期待できる。

ところで, 第 6 国のフィル夕は原理的に一定の点弧 角，負荷抵抗のもとでのみ無效雷力の補償ができる。

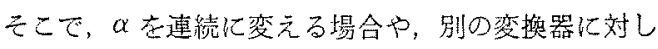
てはよ゙のような回路が害用的で好ましいか，また除去 できなかった高次落調波分芫よ゙う处理するか，が今後 に残された問題点で方る。

終わりに，本研究の一部は昭和 46 年度文部省科学 研究費の援助によって行なわれた。

(昭和 46 年 9 月 2 日受付, 同 47 年 1 月 19 日再受付)

\section{文献}

(1) M.S. Erlicki, et al. IEEE Trans. Industr. Gen. Applic. IGA-4, 4, $444(1968-7 / 8)$

(2) H. Rissik: J. Instn Elect. Engrs 72, 437, 435 (1933-5)

(3) S. B. Dewan, et al. : IEEE Trans. Industr. Gen. Applic. IGA-6, 4, 378 (1970-7/8)

(4) B.D. Bedford, et al, : Principles of Inverter Circuits p. 287

\section{付 録}

\section{Type1フィルタの基本式}

第7図（a）の

$i_{1}, i_{2}, e_{c}$ は次式で与えられる。

$$
\begin{aligned}
& i_{1}(\theta) / \omega C E_{m}=\left\{k_{1}^{2} /\left(k_{1}{ }^{2}-1\right)\right\}\left(\cos \theta-\cos k_{1} \theta\right) \\
& -\left(k_{1} E_{c 1} / E_{m}\right) \sin k_{1} \theta \quad\left(0 \leq \theta \leq \alpha_{f}\right) \\
& i_{2}(\theta) / \omega C E_{m}=\left\{k_{1}^{2}\left(k_{1}{ }^{2}-1\right)\right\}\{\cos \theta \\
& \left.-\cos \alpha_{f} \cos k_{2}\left(\theta-\alpha_{f}\right)+k_{2} \sin \alpha_{f} \sin k_{2}\left(\theta-\alpha_{f}\right)\right\} \\
& -k_{2}\left(E_{c 2} / E_{m}\right) \sin k_{2}\left(\theta-\alpha_{f}\right)\left(\alpha_{f} \leq \theta \leq \beta\right) \\
& e_{c}(\theta) \begin{cases}=e_{c 1}(\theta)=\frac{1}{\omega c} \int i_{1}(\theta) d \theta & \left(0 \leq \theta \leq \alpha_{f}\right) \\
=e_{c 2}(\theta)=\frac{1}{\omega c} \int i_{2}(\theta) d \theta & \left(\alpha_{f} \leq \theta \leq \beta\right)\end{cases}
\end{aligned}
$$

ただし， $\theta=\omega t ， k_{1}, k_{2}$ は (16) 式参照 定常動作を行なうための次の条件式を解いて，第 9 因一第 10 図を得る。
(a) $e_{c 1}\left(\alpha_{f}\right)=e_{c 2}\left(\alpha_{f}\right)=E_{c 2}$
(b) $e_{c 2}(\beta)=-e_{c 1}(0)=E_{c 1}$
(c) $i_{1}\left(\alpha_{f}\right)=0 . \quad i_{2}(\beta)=0$
(d) $e_{c 2}(\beta)=E_{m} \sin \beta$ 